\title{
The Chromosomal Pattern in Leber's Disease*
}

\author{
F. CLIFFORD ROSE and A. I. FRIEDMANN
}

\author{
From the Royal Eye Medical Ophthalmology Unit, Lambeth Hospital, London
}

Leber's disease, as distinct from the autosomal dominant and recessive varieties of optic atrophy, is a genetic puzzle. The transmission of the disease by the unaffected sisters of affected men suggests recessive sex-linked inheritance, but this is excluded by the fact that the daughters of affected men are never carriers. Indeed, no affected man has been known to transmit the disease. A patient with Leber's disease is the end of a line, and transmission is typically through a line of unaffected women. There is the further problem that a considerable proportion of carrier women-as many as $20 \%$ in some families-are themselves affected.

Alternative hypotheses to monofactorial inheritance have been postulated, e.g. modifying genes, cytoplasmic factors, and lethal factors in the sperm of affected men, but none of these suggestions has any convincing support.

The possibility that there is a chromosomal anomaly in Leber's disease has been repeatedly advanced but there is as yet only one observation, on two cases, given in a preliminary note (van Senus, 1963). As in the present report, a normal chromosome pattern is recorded.

\section{Case Report}

A 2 I-year-old man (W.S.) was referred to the Royal Eye Medical Ophthalmology Unit with a history that six months previously he had noticed, when reading, that some words and letters were missing; over the subsequent two months there was a gradual deterioration of central vision that could not be improved with glasses. When first seen he had difficulty in driving and was unable to read a newspaper.

Family History. Two other affected men are known in the family (Fig. I, III. 5 and II. 3 ). In addition there is a suggestive history for three other men (I. 2, I. 3 , and II. 2). The personal details are as follows.

IV. 4. The proband.

III. 5. Uncle of the proband. He was well until the age of 39 when vision in his left eye became obscured and this was followed six months later by poor vision in his right eye; he found he could see better by looking

\footnotetext{
* Received July Io, I964.
}

to one side of an object. Examination revealed bilateral optic atrophy with central scotomata. Visual acuity: L. I/60; R. I $/ 60$.

II. 2. He was not seen but it is reported that he had to read with a magnifying glass. He died at the age of 44 .

II. 3. His vision began to fail at the age of 19 years. Examination revealed bilateral optic atrophy and central scotomata. Now aged $\mathbf{7 4}$ he works in a factory for the blind.

I. 2. Said to have similar trouble but recovered partial sight.

I. 3. Said to have had similar trouble and he was almost completely blind.

The Proband. There was no abnormality shown on general examination other than acne of the face and chest. Visual acuity in the left eye was counting fingers only and in the right eye was $3 / 60$. Hypermetropia of 3.25 D. was present in each eye. The fundus showed slight oedema of both discs, and the crowding characteristic of high hypermetropia. Both maculae showed loss of foveal reflexes. Charting of the visual fields showed a bilateral dense central scotomata within I5 degrees of fixation. The oedema of the left optic disc subsided and his visual acuity six months after his admission was L. I/60, R. 2/60.

The diagnosis of Leber's disease was made on the grounds of age, sex, family history, and acute deterioration of central vision with papillitis.

1

II

III
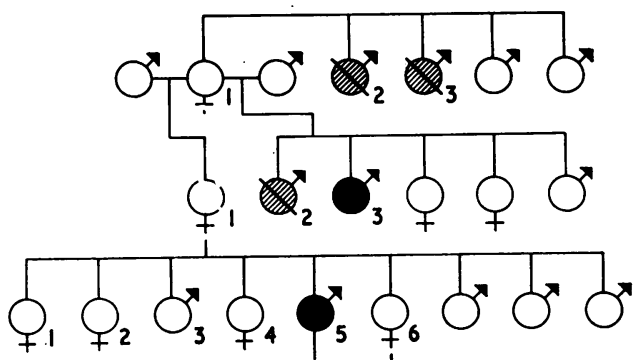

IV

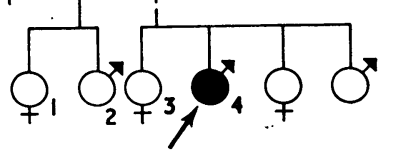

afFected seen

Reputedly affected

FIG. I. The family tree. 
Investigations. Haemoglobin, white cell count, and sedimentation rate were normal. The Wassermann reaction was negative and serum electrolytes and blood urea were normal, as were the serum proteins and protein paper electrophoresis. The urine and the cerebrospinal fluid were normal. Radiograph of the chest showed no abnormality. An electroencephalogram was done and was within normal limits.

Chromosomal Analysis of the Proband and his Mother. (a) Proband. Blood culture report: modal number, 46; sex chromosomes, $\mathrm{XY}$; autosomes, normal.

(b) His mother. Blood culture report: modal number 46; sex chromosomes, XX; autosomes, 3 cells with 45 chromosomes showing random loss. Conclusion : a normal female.

\section{Summary}

As in the two other cases of Leber's disease where the chromosomal pattern was determined, the present study of a typical case showed a normal karyogram. The patient's mother, too, showed a normal karyogram.

We are grateful to Professor Paul Polani and to Dr J. L. Hamerton of the Paediatric Research Unit, Guy's Hospital, for undertaking chromosomal analysis.

\section{REFBRBNCB}

van Senus, A. H. C. (I963). Leber's disease in the Netherlands. Docum. ophthal. (Den Haag), 17, 1. 